\title{
Reporting Complications in Radical Cystoprostatectomy and Orthotopic Neobladder in Male Patients Using a Standard Reporting Methodology
}

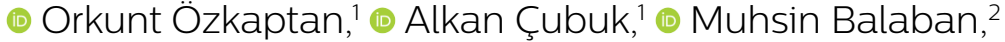

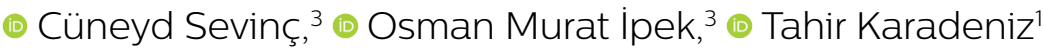

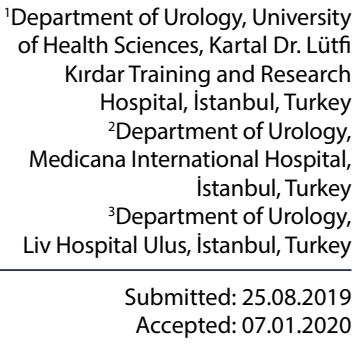

'Department of Urology, University of Health Sciences, Kartal Dr. Lütfi Kırdar Training and Research Hospital, Istanbul, Turkey ${ }^{2}$ Department of Urology, Medicana International Hospital İstanbul, Turkey ${ }^{3}$ Department of Urology, Liv Hospital Ulus, İstanbul, Turkey

Submitted: 25.08 .2019 Accepted: 07.01.2020

Correspondence: Orkunt Özkaptan Sağlık Bilimleri Üniversitesi, Kartal Dr. Lütfi Kırdar Eğitim ve Araştırma Hastanesi, Üroloji Kiliniği, Istanbul, Turkey E-mail:orkunt79@gmail.com

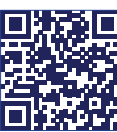

Keywords: Orthotopic neobladder; postoperative complication; radical cystoprostatectomy; standard methodology.

This work is licensed under a Creative Commons Attribution-NonCommercial 4.0 International License.

\begin{abstract}
Objective: This study aims to evaluate the 90-day complication rate and 3-month mortality after open radical cystoprostatectomy using a standardized method to report complications.
\end{abstract}

Methods: We retrospectively reviewed the data of 209 RC male patients operated by the same surgical team between March 2008 and December 2017 in our institution. Patients' characteristics, clinical outcome, pathological parameters and reflectors of surgical difficulty were retrospectively collected from the hospital medical record. Postoperative complications were graded according to the Clavien-Dindo classification, whereas Martin criteria were used to report complications. SPSS version 22.0 was used for the statistical analyses.

Results: A total of 239 complications developed in 143 of the 198 patients (72.2\%). Thirtynine (19.7\%) of these complications occurred after thirty days postoperatively. The mean

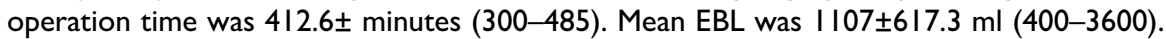
Overall mean hospitalization time was 19.2 \pm 7.3 days (7-30). Perioperative transfusion was given in $78.8 \%$ of the patients $(n=156)$. Major complications (Clavien 3-5) were observed in $4 \mathrm{l}(20.7 \%)$ patients. The most common complication categories were gastrointestinal (28.8\%). Ileus was the most common complication, occurring in $21.2 \%$ of the patients.

Conclusion: Our results support the consideration of a more extended follow-up period to define the morbidity of RC. The standardization of the reporting criteria for complications will allow direct comparisons between studies. The complication rates after utilizing a standard reporting methodology were higher compared to studies that do not employ such methodologies.

\section{INTRODUCTION}

The gold standard treatments for patients with muscleinvasive bladder cancer or high-grade noninvasive transitional cell carcinoma is radical cystectomy (RC), including extended pelvic lymph node dissection, and urinary diversion. ${ }^{[l]}$ RC, including pelvic lymph node dissection, provides excellent local cancer control with up to $50-70 \%$ cancer-specific survival. ${ }^{[2]}$

Even surgical technique and postoperative care improve $\mathrm{RC}$ is still associated with high perioperative mortality and complication rates varying between $20 \%$ and $57 \% \%^{[3-10]}$ and
$0.3 \%$ and $5.7 \%$, respectively. ${ }^{[4,7-10]}$ A formal complication system was not used in most of the studies that reported on complication and morbidity, thus, making it difficult to compare different studies and to create a definition of morbidity for the procedure. ${ }^{[4]}$ Martin et al. ${ }^{\left[{ }^{[1]}\right]}$ established 10 factors for reporting surgical complications to provide an objective and more accurate reporting method of complications. The criteria comprised risk factor analysis, follow-up duration, data accrual methods, complication definitions, outpatient information, mortality and morbidity rates, procedure-specific complication, severity grading and hospital stay. Further, Shabsigh et al. ${ }^{[2]}$ used these 10 critical reporting elements to define the type, incidence, 
and severity of early postoperative morbidities following $\mathrm{RC}$.

There is a shift toward continent diversion during the last years. However, it is reported that orthotopic neobladder is associated with a complication rate of about $50 \%$ even at referral centres. ${ }^{[13]}$

The type of urinary diversion reporting complications is not stratified in most of the studies. In the recent study, we report the 90-day complication rates of male patients who underwent RC and orthotopic neobladder using a standard method reporting complications.

\section{MATERIALS AND METHODS}

We retrospectively reviewed the data of $209 \mathrm{RC}$ male patients operated by the same surgical team between March 2008 and December 2017 in our institution. A written waiver was provided from each patient. Ethical approval was obtained from the Ethical Committee of our institution (Medicana International Hospital No 430-2020). The Martin criteria were used for collecting the data of early postoperative complications. ${ }^{\left[{ }^{\prime \prime}\right]}$ Patients $(\mathrm{Nn}=10)$ who received neoadjuvant chemotherapy were excluded from the study.

The pathological parameters and patients characteristics, including age, ASA score ( $2 \leq$ vs. $>2)$, estimated blood loss (EBL), operative time (OT), pathological stage, radiological interventions, readmissions, transfusion rate (TR), hospital stay (HS) and clinical outcome, were retrospectively collected from the hospital medical record. Indications for an orthotopic neobladder were normal kidney function (creatinine clearance $>40 \mathrm{ml}$ per minute or creatinine less than $2 \mathrm{ng} / \mathrm{dl}$ ), absent disease at the level of the bladder neck and prostatic urethra, and patient request for orthotopic neobladder substitution. The 2012 TNM system was used for reporting pathological stage.

Low-molecular-weight heparin was started on the evening before surgery and was maintained until the 30th postoperative day. Third-generation cephalosporin was used as prophylaxis for infection, and elastic compressive stockings were used for preventing thromboembolic events, respectively, in all patients. Patients received two high enemas the night before and in the morning before surgery.

Open RC and pelvic lymphadenectomy were performed in the standard fashion. The neobladder was performed using a modified Studer technique, while ureteral anastomosis was performed using the Wallace and Bricker technique. A $45-\mathrm{cm}$ ileal part was isolated for the neobladder reconstruction $20-\mathrm{cm}$ proximal to the ileocecal valve. All patients spent one night in the intermediate care unit according to our institutional protocol. A nasogastric tube was left in place until recovery of bowel activity after surgery, usually until postoperative day 3 or 4 . A cystogram was performed when elevated creatinine levels of the drainage fluid were determined and routinely before removal of the catheter, usually postoperative tenth day.
Daily clinical examinations and laboratory monitoring were performed in a standard fashion. All patients underwent a physical examination, blood tests, urine culture and abdominopelvic computed tomography during the thirdmonth visits. A modified version of the original ClavienDindo grading system was used for reporting complications within 90 days. ${ }^{[14]}$ Major complications were defined as grade 3 to 5 and minor or no complications as grade 0 , I, and 2. Complications that developed after discharge were collected by reviewing the medical records at our outpatient clinic.

Statistical analyses were performed using the Statistical Package for the Social Sciences 22.0 (SPSS, Chicago, IL, USA). Continuous variables were reported as the mean \pm $\mathrm{SD}$. Categorical variables were reported as numbers and percentages.

\section{RESULTS}

Table I presents the clinical characteristics, perioperative and postoperative outcomes and pathological evaluations. All the patients were male. The 90-day postoperative mortality rate was $2 \%(n=4)$.

\section{Operative characteristics}

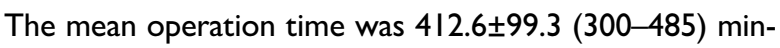
utes. Mean EBL was II07 $\pm 617.3 \mathrm{ml}$ (400-3600). Perioperative transfusion rate was given in $78.8 \%$ of the patients $(n=156)$. No major intraoperative complications occurred. Four patients (4\%) were admitted to the intensive care unit for a median of two days. The median time for the removement of the indwelling catheter was 13 days (range I2-2I).

Reoperation due to the surgical complication was required in three patients (1.51\%). Six (3\%) patients required interventional radiology procedures. Overall mean hospitalization time was 19.2 \pm 7.3 days (7-30).

Overall, 239 complications developed in 143 of the 198 patients (72.2\%). Most of these were gastrointestinal complications. Thirty-nine (19.7\%) of these complications occurred after thirty days postoperatively. Infection was the most commonly occurring complication after thirty days $(n=75,37.9 \%)$.

Major complications (Clavien 3-5) were observed in $4 \mathrm{I}$ (20.7\%) patients. In 3 I (I5.7\%) patients, grade 3 complications were observed (such as urinary leakage, reoperation for fascial dehiscence, bleeding, evisceration, urinoma). Six patients (3\%) had grade 4 complications, and four (2\%) died within three months of surgery (grade 5). All four patients died of cardiopulmonary events (myocardial infarction or pulmonary embolism). One $(0.5 \%)$ of these patients died between the 30 days to 90 -day postoperative period. Of the patients, 102 (5I.5\%) had grade I-2 complications. The most common complication categories were gastrointestinal $(n=56,28.28 \%)$ and wound-related $(n=45$, $22.72 \%$ ). Ileus was the most common individual complication, occurring in $21.2 \%$ of patients. Wound infections 
Table I. Clinical characteristics, perioperative and postoperative outcomes and the pathological evaluations

\begin{tabular}{|c|c|}
\hline \multicolumn{2}{|l|}{ Variable } \\
\hline Patient number & 198 \\
\hline Age, year, mean $\pm S D$ (range) & $\begin{array}{c}61.1 \pm 10.68 \\
(28-81)\end{array}$ \\
\hline${ }^{\dagger} \mathrm{BMI}$, mean $\pm \mathrm{SD}$ (range) & $\begin{array}{c}25.83 \pm 2.80 \\
(19.47-36.21)\end{array}$ \\
\hline \multicolumn{2}{|l|}{${ }^{\ddagger}$ ASA score, $n(\%)$} \\
\hline 1 & $52(26.3)$ \\
\hline 2 & $80(40.4)$ \\
\hline 3 & $54(27.3)$ \\
\hline 4 & $12(6.1)$ \\
\hline Operating time, minutes, mean $\pm \mathrm{SD}$ (range) & $\begin{array}{c}412.6 \pm 99.3 \\
(300-485)\end{array}$ \\
\hline Hospitalization time, day, mean $\pm S D$ (range) & $\begin{array}{c}19.2 \pm 5.4 \\
(7-30)\end{array}$ \\
\hline Estimated blood loss, ml, mean \pm SD (range) & $\begin{array}{c}1102 \pm 617.3 \\
(400-3600)\end{array}$ \\
\hline Perioperative transfusion, $\mathrm{n}(\%)$ & $156(78.8)$ \\
\hline \multicolumn{2}{|l|}{ Pathological stage, n (\%) } \\
\hline $\mathrm{pTa}$ & $4(2.0)$ \\
\hline pTis & $3(1.5)$ \\
\hline PTI & $8(4.0)$ \\
\hline $\mathrm{pT} 2$ & $98(49.5)$ \\
\hline pT3 & $81(40.9)$ \\
\hline $\mathrm{pT} 4$ & $4(2.0)$ \\
\hline \multicolumn{2}{|l|}{ Pathological lymph node, $\mathrm{n}(\%)$ status } \\
\hline No & $137(69.1)$ \\
\hline $\mathrm{N}+$ & $61(30.8)$ \\
\hline Organ confined disease & $102(5 \mid .5)$ \\
\hline Concomitant Cis, status & $10(6.3)$ \\
\hline \multicolumn{2}{|l|}{${ }^{\circledR}$ Clavien-Dindo classification, $\mathrm{n}(\%)$} \\
\hline Major $3 \leq$ & $4 I(20.2)$ \\
\hline Minor I-2 & $102(51.5)$ \\
\hline
\end{tabular}

BMI: Body mass; index; ASA: American Society of Anesthesiologists (classification); SD: Standard deviation; §Grade 0: No complications; Grade I: Complications needing only oral medications or bedside intervention; Grade 2: Complications needing only intravenous medications, total parenteral nutrition, or blood transfusion; Grade 3: Complications needing interventional radiology, therapeutic endoscopy, intubation, angiography or surgery; Grade 4: Complications causing residual and lasting disability requiring major rehabilitation or organ resection; Grade 5: Complications causing death.

(12.12\%, $n=24)$ and urinary infections ( $11.61 \%, n=23)$ were other common individual complications. Wound dehiscence managed with local wound care occurred in 12 $(6.04 \%)$ of patients, fascial dehiscence requiring reoperation occurred in three ( $1.51 \%)$ of patients. The most common complication of the genitourinary system was acute renal failure occurring in seven patients $(3.50 \%)$, whereas urinary leakage was determined in three ( $1.51 \%)$ patients. Arrhythmia was the most common cardiac morbidity observed in $10(5.05 \%)$ patients. Myocardial infarction was observed in three $(1.51 \%)$ of the patients. The most com-
Table 2. Incidences of early complications (first 90 postoperative days)

\begin{tabular}{|c|c|}
\hline $\begin{array}{l}\text { Early complications } \\
\text { (first } 90 \text { postop. days) }\end{array}$ & No. total (\%) \\
\hline Gastrointestinal (GIS) & $56(28.8 \%)$ \\
\hline lleus & 42 \\
\hline Constipation & 5 \\
\hline Diarrhoea & 4 \\
\hline Intestinal bleeding & 2 \\
\hline Emesis & 2 \\
\hline Pancreatitis & I \\
\hline Infection & 39 (19.7\%) \\
\hline Urinary tract infection & 23 \\
\hline Fever unknown origin & 11 \\
\hline Urosepsis & 2 \\
\hline Pyelonephritis & 2 \\
\hline Gastroenteritis & I \\
\hline Wound & $45(22.7 \%)$ \\
\hline Wound infection & 24 \\
\hline Wound dehiscence & 12 \\
\hline Wound seroma & 9 \\
\hline Fascial dehiscence/evisceration & 2 \\
\hline Genitourinary & $14(7.1 \%)$ \\
\hline Renal failure & 7 \\
\hline Urinary leak & 3 \\
\hline Urinary retention & 2 \\
\hline Neobladder bleeding & 2 \\
\hline Cardiac & $22(11.1 \%)$ \\
\hline Arrhythmia & 10 \\
\hline Myocardial infarction & 3 \\
\hline Hypertension & 3 \\
\hline Angina & 4 \\
\hline Syncope/hypotension & 2 \\
\hline Pulmonary & $15(7.6 \%)$ \\
\hline Pneumonia & 6 \\
\hline Respiratory distress & 5 \\
\hline Pleural effusion & 2 \\
\hline Atelectasis & 2 \\
\hline Bleeding & 31 (15.6\%) \\
\hline Anaemia requiring transfusion & 27 \\
\hline Draine side bleeding & I \\
\hline Perioperative vascular bleeding & 3 \\
\hline Thromboembolic & $10(5 \%)$ \\
\hline Deep venous thrombosis & 6 \\
\hline Pulmonary embolism & 4 \\
\hline Neurological & $3(1.5 \%)$ \\
\hline Encephalitis & I \\
\hline Loss of consciousness & 1 \\
\hline Delirium/agitation & I \\
\hline Miscellaneous & $7(3.5 \%)$ \\
\hline Dermatitis & 2 \\
\hline Acidosis & 2 \\
\hline Lymphocele & 2 \\
\hline Decubitus ulcer & I \\
\hline
\end{tabular}


mon pulmonary comorbidity was pneumonia, affecting six $(3.03 \%)$ of the patients. Deep venous thrombosis and pulmonary embolism developed in six $(3.03 \%)$ and four (2.02\%) patients, respectively.

Emergency room visits were required in 24 (12.12\%) patients, of whom, I 3 (6.56\%) were readmitted. The majority of readmissions were due to gastrointestinal and infectious complications $(n=10,5.05 \%)$. Further information about complications is listed in Table 2.

\section{DISCUSSION}

$\mathrm{RC}$ reduces the risk of death from bladder cancer after controlling for disease grade and stage. ${ }^{[5]}$ The orthotopic neobladder should be the primary procedure for urinary diversion following RC because of the possibility of maintaining anatomy and function close to the natural preoperative status. ${ }^{[15]}$ In our patients, the Studer orthotopic neobladder is offered to those who are eligible for $\mathrm{RC}$ and who do not have contraindications.

Many studies regarding complications have been published, but most of them did not use accurate grading systems or a standard methodology. We attempted to fulfil the Martin criteria for reporting complications after surgery. $\left.{ }^{[1}{ }^{1}\right]$ Donat et al. ${ }^{[6]}$ reported that the disparity in reporting surgical complications in urologic oncology makes it difficult to compare the morbidity associated with surgical outcomes and surgical techniques among different institutions and surgeons. Afterwards, studies were published using standardized methodologies to report the outcomes and complications in RC. ${ }^{[12,17]}$

The overall 90-day postoperative complication rate in our study was $72.2 \%$. This result is comparable with that of recent studies using systemic classification criteria, including minor complications. ${ }^{[12]}$ In the study by Lowrance et al., ${ }^{[18]}$ the rate of the 30-day postoperative complications was $41 \%$. The 30 -day complication rate in our study was $52.2 \%$. Another study reported a 90 -day postoperative complication rate of $64 \%$ and noted the difference in complication rates between postoperative 30 days and 90 days. They stated that an important part of complications occurred after postoperative 30 days. ${ }^{[12]}$ The results of our study support this argument, as $19.7 \%$ of the complications occurred after 30 days. These complications would have been missed if the Martin criteria were not be applied. The complication rates noted in the studies using classification systems are higher than reported in previous studies that did not. Complications in these previous studies, without the standardization of reporting complications and/or clear definitions of complications, ranged between 28.4 and 39\%. [4-6,19] Certainly, surgeon experience, technique, and institutional differences may also explain the dissimilarities in complication rates. The reporting of 90-day complications, with the inclusion of outpatient complications, might be another reason for the higher complication rates in our study. As Shabsigh et al. ${ }^{[12]}$ reported, $21 \%$ of complications in their study would have been missed if only inpatient complica- tions were reported instead of 90-day findings. Other reasons for the higher complication rates in our study group may stem from the longer HS (19.2 days). This allowed a more precise assessment and recording of complications. The results of our data revealed higher grade 3-5 complications rates as opposed to findings in previous studies, ${ }^{[12,16]}$ although the median patient age and ASA scores were similar. The EBL rate was higher in our study compared to other studies, and this may be another reason for the higher major complication rates. Because our study included only patients with orthotopic neobladder, substitution could be another explanation for the higher complication rates. It should be mentioned that some complications are disposed to occur after foley catheter and drains were removed in orthotopic neobladder. The most frequent complications in our study were related to the gastrointestinal tract (21.2\%; ileus) and wound infection ( $12.1 \%$ ). Ileus rates were similar to that in a previous study where ileus was similarly defined (23\%). ${ }^{[12]}$

The postoperative mortality rate was $2 \%$ in the present study. Three of the patients died in the first 30 days, whereas one patient died between the 30 to 90 day time period in our study. One patient would have been missed if a 90-day period of complications had not been reported. Previous studies reported mortality rates in the perioperative period or 30-day mortality rates, and this period might not include all surgery-related deaths that might have occurred after 30-days postoperatively. Shabsigh et al. ${ }^{[2]}$ expanded the definition of perioperative mortality to a 90 -day period, which may yield higher mortality rates.

The limitations of our study include the retrospective collection of data. Another limitation is the relatively low sample size. A bigger patient cohort may help to identify other factors that are predictive of complications. Moreover, our study population included only male patients with an orthotopic neobladder. Patients with ileal conduit or female patients were excluded.

\section{CONCLUSION}

Our results support the consideration of a longer followup period to define the morbidity of RC. The standardization of the reporting criteria for complications will allow direct comparisons between studies. The complication rates after utilizing a standard reporting methodology were higher compared to studies that do not employ such methodologies. The accurate reporting of complications and assessment of factors that affect the perioperative course and complications should allow for improved preoperative risk stratification and counselling.

\section{Ethics Committee Approval}

Approved by the local ethics committee (Medicana International Hospital No 430-2020).

Informed Consent

Retrospective study. 
Peer-review

Internally peer-reviewed.

Authorship Contributions

Concept: O.Ö.; Design: M.B.; Supervision: T.K.; Materials: O.Ö.; Data: O.M.I.; Analysis: O.Ö.; Literature search: C.S.; Writing: O.Ö.; Critical revision: A.Ç.

\section{Conflict of Interest}

None declared.

\section{REFERENCES}

1. Stenzl A, Cowan NC, De Santis M, Jakse G, Kuczyk MA, Merseburger AS, et al. The updated EAU guidelines on muscle-invasive and metastatic bladder cancer. Eur Urol 2009;55:815-25. [CrossRef]

2. Shariat SF, Karakiewicz PI, Palapattu GS, Amiel GE, Lotan Y, Rogers CG, et al. Nomograms provide improved accuracy for predicting survival after radical cystectomy. Clin Cancer Res 2006;12:6663-76.

3. Studer UE, Burkhard FC, Schumacher M, Kessler TM, Thoeny H, Fleischmann A, et al. Twenty years experience with an ileal orthotopic low pressure bladder substitute--lessons to be learned. J Urol 2006;176:161-6. [CrossRef]

4. Chang SS, Cookson MS, Baumgartner RG, Wells N, Smith JA Jr. Analysis of early complications after radical cystectomy: results of a collaborative care pathway. J Urol 2002;167:2012-26. [CrossRef]

5. Hollenbeck BK, Miller DC, Taub D, Dunn RL, Khuri SF, Henderson WG, et al. Identifying risk factors for potentially avoidable complications following radical cystectomy. J Urol 2005;174:1231-7

6. Konety BR, Allareddy V, Herr H. Complications after radical cystectomy: analysis of population-based data. Urology 2006;68:58-64.

7. Quek ML, Stein JP, Daneshmand S, Miranda G, Thangathurai D, Roffey $\mathrm{P}$, et al. A critical analysis of perioperative mortality from radical cystectomy. J Urol 2006;175:886-9. [CrossRef]

8. Novotny V, Hakenberg OW, Wiessner D, Heberling U, Litz RJ, Oe- hlschlaeger S, et al. Perioperative complications of radical cystectomy in a contemporary series. Eur Urol 2007;51:397-401. [CrossRef]

9. Fairey A, Chetner M, Metcalfe J, Moore R, Todd G, Rourke K, et al. Associations among age, comorbidity and clinical outcomes after radical cystectomy: results from the Alberta Urology Institute radical cystectomy database. J Urol 2008;180:128-34. [CrossRef]

10. Boström PJ, Kössi J, Laato M, Nurmi M. Risk factors for mortality and morbidity related to radical cystectomy. BJU Int 2009;103:1916. [CrossRef]

11. Martin RC 2nd, Brennan MF, Jaques DP. Quality of complication reporting in the surgical literature. Ann Surg 2002;235:803-13.

12. Shabsigh A, Korets R, Vora KC, Brooks CM, Cronin AM, Savage C, et al. Defining early morbidity of radical cystectomy for patients with bladder cancer using a standardized reporting methodology. Eur Urol 2009;55:164-74. [CrossRef]

13. World Health Organization (WHO) Consensus Conference on Bladder Cancer, Hautmann RE, Abol-Enein H, Hafez K, Haro I, Mansson W, et al. Urinary diversion. Urology 2007;69:17-49.

14. Dindo D, Demartines N, Clavien PA. Classification of surgical complications: a new proposal with evaluation in a cohort of $6336 \mathrm{pa}$ tients and results of a survey. Ann Surg 2004;240:205-13.

15. Hautmann RE. Urinary diversion: ileal conduit to neobladder. J Urol 2003;169:834-42. [CrossRef]

16. Donat SM. Standards for surgical complication reporting in urologic oncology: time for a change. Urology 2007;69:221-5. [CrossRef]

17. Novara G, De Marco V, Aragona M, Boscolo-Berto R, Cavalleri S, Artibani W, et al. Complications and mortality after radical cystectomy for bladder transitional cell cancer. J Urol 2009;182:914-21.

18. Lowrance WT, Rumohr JA, Chang SS, Clark PE, Smith JA Jr, Cookson MS. Contemporary open radical cystectomy: analysis of perioperative outcomes. J Urol 2008;179:1313-8. [CrossRef]

19. Lee CT, Dunn RL, Chen BT, Joshi DP, Sheffield J, Montie JE. Impact of body mass index on radical cystectomy. J Urol 2004;172:1281-5.

\section{Radikal Sistoprostatektomi ve Ortotopik Neobladder Komplikasyonlarının Standardize Edilmiş Bir Metodolojiye Göre Sınıflandırılması}

Amaç: Açık radikal sistoprostatektomi (RS) sonrası 90 günlük komplikasyon oranını ve üç aylık mortalite oranını standart bir metodoloji kullanarak bildirmek.

Gereç ve Yöntem: Aynı ameliyat ekibi tarafından Mart 2008-Aralık 2017 tarihleri arasında ameliyat edilen 209 RS erkek hastanın verileri geriye dönük olarak incelendi. Hastaların özellikleri, klinik sonuçları, patolojik parametreleri ve cerrahi güçlük reflektörleri geriye dönük olarak hastane sağılk kayıtlarından toplandı. Ameliyat sonrası komplikasyonlar Clavien-Dindo sınıflamasına göre derecelendirilirken, Martin kriterleri komplikasyonları bildirmek için kullanıldı. İstatistiksel analizler için SPSS 22.0 sürümü kullanıldı.

Bulgular: Yüz doksan sekiz hastanın 143'ünde (\%72.2) toplam 239 komplikasyon gelişti. Bu komplikasyonların otuz dokuzu (\% 19.7) ameliyat sonrası otuzuncu günden sonra meydana geldi. Ortalama ameliyat süresi $412.6 \pm(300-485)$ idi. Ortalama EBL II $07 \pm 617.3 \mathrm{~mL}(400-3600)$ idi. Genel ortalama hastanede kalış süresi 19.2 \pm 7.3 gündü (7-30). Perioperatif transfüzyon hastaların \%78.8'ine verildi $(n=156)$. Kırk bir hastada (\%20.7) majör komplikasyonlar (Clavien 3-5) gözlendi. En sık görülen komplikasyon kategorileri gastrointestinaldi (\%28.8). En sık görülen komplikasyon ileus idi, hastaların \%21.2'sinde meydana geldi.

Sonuç: Radikal sistoprostatektominin morbiditesini tanımlamak için daha uzun bir takip süresinin değerlendirilmesini desteklemektedir. Raporlama kriterlerinin standartlaştııılması, çalışmalar arasında doğrudan karşılaştırma yapılmasına olanak sağlayacaktır. Standart bir raporlama metodolojisi kullandıktan sonra komplikasyon oranları, bu metodolojileri kullanmayan çalısmalara kıyasla daha yüksekti.

Anahtar Sözcükler: komplikasyon; ortotopik neobladder; radikal sistoprostatektomi; standart metodoloji. 